\title{
Exploratory study on the impregnation of Scots pine sapwood (Pinus sylvestris L.) and European beech (Fagus sylvatica $L$.) with different hot melting waxes
}

\author{
G. Scholz $\cdot$ A. Krause $\cdot$ H. Militz
}

Received: 18 January 2010/Published online: 22 June 2010

(C) The Author(s) 2010. This article is published with open access at Springerlink.com

\begin{abstract}
Scots pine sapwood (Pinus sylvestris L.) and beech (Fagus sylvatica L.) were impregnated with five waxes. The experiments indicate deep penetration into pine sapwood. Besides the viscosity, an influence of the wax polarity is presumed. Wax penetrates pine wood deeply via the cross-section, but not sufficiently enough to impregnate longer construction elements. However, the radial wax uptake exceeds the uptake via the tangential orientation and guarantees complete soaking of the sapwood tissue. The lateral wax penetration within beech is quite low and irregular. In addition to the temperature, a prolonged process procedure is decisive for an increasing wax uptake. As such, beech wood vessel elements seem to be fully impregnable via the longitudinal surface after a longer process procedure.
\end{abstract}

\section{Introduction}

Waxes are esters of fatty acids with higher alcohols (Fengel and Wegener 2003). Since ancient times, pure wax has been used as bonding agent for colorants, conservation processes such as mummification or ship building, etc. In addition to numerous patent literatures, the use of waxes by the wood industry is well described in literature (Bub-Bodmar and Tilger 1922; Kollmann 1951; Illmann et al. 1983; Unger et al. 2001). On the one hand, waxes are used as water repellents due to their hydrophobic properties (Borgin and Corbett 1970; Sell 1977; Feist and Mraz 1978; Scholz et al. 2009). But waxes can also be used to improve the hardness and strength

This article is dedicated to Gerd Wegener on the occasion of his retirement as professor at the Technische Universität München.

G. Scholz · A. Krause $\cdot$ H. Militz $(\bowtie)$

Department of Wood Biology and Wood Products,

Georg-August-University Göttingen, Büsgenweg 4, 37077 Göttingen, Germany

e-mail: hmilitz@gwdg.de 
properties of solid wood or already degraded wood (Unger et al. 2001; Mundigler and Rettenbacher 2005; Scheiding 2007; Scholz et al. 2009). Scholz et al. (2010b) found a varying influence of different waxes on the strength properties.

There is not much literature that focuses on the uptake of hot melting waxes in wood. Buro and Buro (1959) and Scholz et al. (2010a) investigated the deposition of hot melting waxes in solid wood. They observed wax-free void space within the parenchyma tissue of pine and beech sapwood such as ray parenchyma cells or resin canals. Furthermore, Scholz et al. (2010a) investigated the uptake of different wax types in wood due to their molecule size and properties. These results and observations are the basis for further investigations in the present article. On the one hand, different impregnations were carried out with varying process parameters, and on the other hand, viscosity and surface tension as important parameters during the impregnation process were determined.

\section{Materials and methods}

Wax impregnation in the main anatomical directions

Scots pine (Pinus sylvestris L.) and beech (Fagus sylvatica L.) sapwood were impregnated with different waxes. The impregnation was carried out with esterified montan acids (wax 1), modified plant wax (wax 2), amid wax (wax 3), paraffin (wax 4) and montan ester wax (wax 5) at $100^{\circ}$ and $120^{\circ} \mathrm{C}$. The wax types were colored with a dye (Fat Blue, Clariant), which in pre-trials showed to have no influence on the penetration of waxes. The determination of the penetration depth took place by ripping the specimens in the middle and measuring the blue-colored wax. The influence of specific wax properties on the lateral penetration depths was examined on ten partly sealed (Pyrotect Company) specimens $\left(40 \times 40 \times 20 \mathrm{~mm}^{3}\right)$ in radial and tangential direction. Some properties of the waxes used are presented in Table 1.

Furthermore, semi-industrial impregnations were carried out with wax type 5 under varying process conditions. The specimens (longitudinal: 1,000 $\times 46 \times$ $46 \mathrm{~mm}^{3}$, lateral: $250 \times 46 \times 46 \mathrm{~mm}^{3}$ ) were partly sealed. Two samples were used

Table 1 Properties of the wax types used

\begin{tabular}{|c|c|c|c|c|c|}
\hline Wax & Product name & Type & $\begin{array}{l}\text { Density } \\
\left(\mathrm{g} \mathrm{cm}^{-3}\right)\end{array}$ & $\begin{array}{l}\text { Melting } \\
\text { point }\left({ }^{\circ} \mathrm{C}\right)\end{array}$ & $\begin{array}{l}\text { Acid number } \\
\left(\mathrm{mg} \mathrm{KOH} \mathrm{g}^{-1}\right)\end{array}$ \\
\hline 1 & Licowax E & $\begin{array}{l}\text { Montan ester } \\
\quad\left(\mathrm{C}_{24}-\mathrm{C}_{34}\right)\end{array}$ & 1.02 & 81 & $15-20$ \\
\hline 2 & Experimental & Natural wax (modified) & 0.99 & 84 & n.d. \\
\hline 3 & Experimental & Amid wax & 0.99 & 78 & n.d. \\
\hline 4 & Paraflint C80 & Fischer-Tropsch-Wax & 0.90 & 83 & None \\
\hline 5 & Licolub WM31 & $\begin{array}{l}\text { Montan ester } \\
\qquad\left(\mathrm{C}_{17}-\mathrm{C}_{34}\right)\end{array}$ & 1.00 & 72 & 10 \\
\hline
\end{tabular}


per direction and process. The sealing was carried out with a finish (Pyrotect-2 K, Dreisol) by covering five of the six surfaces on the cubiform or block-shaped specimens. Therefore, one cross-section (longitudinal penetration) or radial (tangential p.) or tangential (radial p.) surface remained unsealed.

The impregnation processes took place under vacuum-pressure at $100^{\circ}$ and $120^{\circ} \mathrm{C}$, respectively. The experimental design is presented in Table 2 . The wax uptake (WPG) was calculated according to Eq. 1, where $m$ is the specimen mass before $(u)$ and after $(t)$ the treatment. Measurement of the penetrated waxes followed as already mentioned. The specimens were cut two times (longitudinal) and four times (lateral) to determine the penetration depth and wax extension. The longitudinal penetration was sometimes difficult to determine, that is why the median of the four values was used. Single outliers were noticed.

$$
\mathrm{WPG}=\frac{m_{t}-m_{u}}{m_{u}} \times 100 \%
$$

Determination of the viscosity and surface tension of waxes

The viscosity characterizes the fluid properties of liquids, which depend on temperature and pressure, whereas the dynamic viscosity considers the internal friction between the molecules (Atkins 1993). The dynamic viscosities were determined with a rheometer (Physica MCR 101, V2.81; ANTON PAAR). The shear rate amounted to $100 \mathrm{~s}^{-1}$. Additionally, the viscosities of two further waxes with different chemical composition were determined. The waxes used were glycerin ester wax (Licolub WE4, Clariant) and polyethylene wax (Licocene PE 4201, Clariant).

Surface tension $(\sigma)$ was determined with the capillary method. According to Wittmann (2000), the height of the fluid column rising in the capillary is calculated with Eq. 2. The determination of the capillary ascent of water and molten wax was carried out using glass tubes with a radius of $r_{k}=0.4 \mathrm{~mm}$. Furthermore, the acceleration of gravity $g\left(9.80665 \mathrm{~m} \mathrm{~s}^{-2}\right)$ and the density of the waxes $\rho_{F}$ were used.

$$
h=\frac{2 \cdot \sigma}{g \times \rho_{F} \times r_{k}}
$$

Table 2 Experimental design of the processes carried out at 100 and $120^{\circ} \mathrm{C}$

\begin{tabular}{lllll}
\hline Vacuum (mbar) & $\begin{array}{l}\text { Duration (min) } \\
\text { Vacuum/pressure }\end{array}$ & \multicolumn{3}{l}{ Pressure (bar) } \\
\cline { 3 - 5 } & & 4 & 8 & 12 \\
\hline Semi-industrial & & & & \\
100 & $20 / 27$ & $X$ & $X$ & $X$ \\
& $120 / 240$ & & & $X$ \\
Laboratory & & & & \\
200 & $20 / 27$ & & $X$ & \\
\hline
\end{tabular}




\section{Results and discussion}

Wax impregnation in the main anatomical directions

Figures 1, 2, 4 and 6 present the results of lateral wax penetration in pine sapwood and beech. The impregnations presented in Fig. 1 and 2 were carried out under a vacuum-pressure process ( 8 bar) at $100^{\circ} \mathrm{C}$ for $47 \mathrm{~min}$. European beech is difficult to impregnate with liquid wax via the lateral surfaces, in contrast to pine sapwood (Fig. 4). Within pine, significant differences between the radial and tangential directions are observed (Fig. 1, 4 and 6). The deeper penetration depth in the radial direction of pine can be explained by Buro and Buro (1959) and Scholz et al. (2010a). These authors observed wax deposits in the ray tracheids of pine. For this reason, the conductance of ray tracheids explains the better radial wax penetration into pine sapwood.

However, the radial and tangential penetrations in beech are quite similar to each other (Fig. 2 and 5) and show much lower penetration depth compared to that of pine. According to the cited authors, this could be explained by the absence of conductance for liquids via the parenchyma tissue (Buro and Buro 1959; Scholz et al. 2010a). On the other hand, it is more difficult for non-polar particles such as carbon (Murmanis and Chudnoff 1979) or wax to cross the hardwood pits due to

Fig. 1 Lateral wax penetration into pine sapwood (vacuumpressure treatment at $100^{\circ} \mathrm{C}$ )
Fig. 2 Lateral wax penetration into beech (vacuum-pressure treatment at $100^{\circ} \mathrm{C}$ )
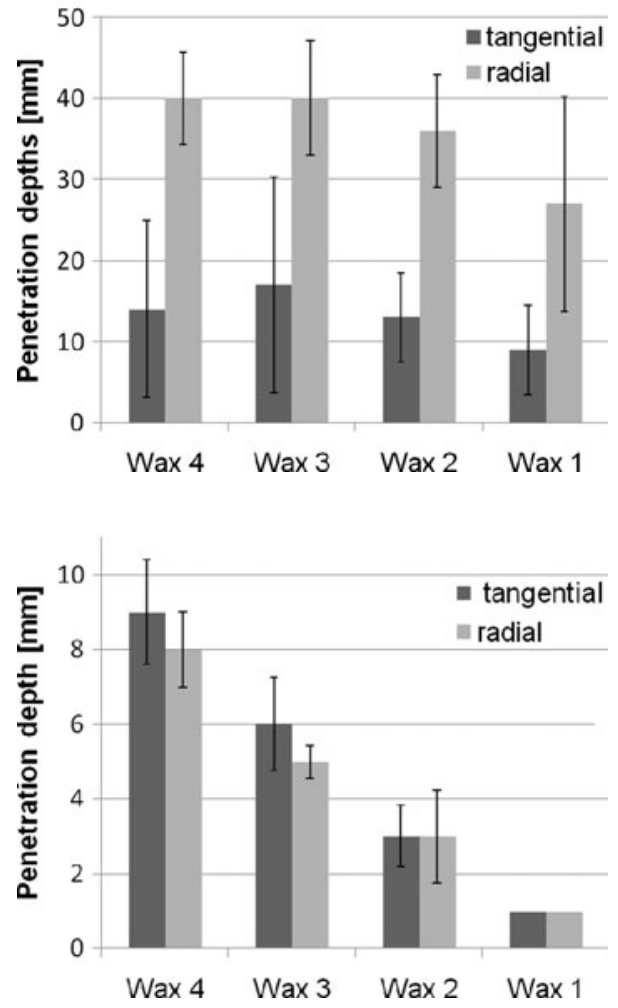
Table 3 Physical and chemical properties of the investigated waxes

\begin{tabular}{lcll}
\hline Wax & $\begin{array}{l}\text { Viscosity } \\
\left(100^{\circ} \mathrm{C}\right) \\
{[\mathrm{mPas}]}\end{array}$ & $\begin{array}{l}\text { Viscosity } \\
\left(120^{\circ} \mathrm{C}\right) \\
{[\mathrm{mPas}]}\end{array}$ & $\begin{array}{l}\text { Surface tension } \\
\left(100^{\circ} \mathrm{C}\right) \\
{\left[\mathrm{mN} \mathrm{m}^{-1}\right]}\end{array}$ \\
\hline 1 & 27.9 & 18.0 & 38.3 \\
2 & 9.9 & 8.8 & 41.5 \\
3 & 10.8 & 7.9 & 29.4 \\
4 & 9.4 & 5.4 & 42.0 \\
5 & 23.4 & 14.8 & 33.7 \\
$\mathrm{H}_{2} \mathrm{O}$ & 1.0 & - & 72.7 \\
\hline
\end{tabular}

their membrane structure (Scholz et al. 2010a). In Fig. 2, the penetration of waxes with different polarity and viscosity are demonstrated. Wax 4 has no polarity and a viscosity of $9.4 \mathrm{mPa} \mathrm{s}$ at $100^{\circ} \mathrm{C}$. The acid number of wax 1 lies between 15 and 20 $\mathrm{mg} \mathrm{KOH} \mathrm{g}{ }^{-1}$, and it has a viscosity of $28 \mathrm{mPa}$ s (q.v. Scholz et al. 2010a). The importance of the polarity is obvious for wax 3 and wax 2 (Fig. 2). Although it has a slightly lower viscosity and comparable molecule size (Table 3, Scholz et al. 2010a), wax 2 does not penetrate across the lateral surface like wax 3. This can possibly be explained by an influence of polar groups such as ester bonds or free carboxyl groups and their reactivity with each other and with the hydroxyl groups of the cell wall.

The results of the impregnations on the semi-industrial scale are presented in Fig. 3, 4, 5 and 6 . Waxes penetrate wood longitudinally via tracheids, fibers and vessels like other fluids too. The effective capillary radius influences the penetrating fluid volume exponentially (exponent 4) according to Poiseuille's equation. The longitudinal penetration of softwood from tracheid to tracheid across bordered pits is marginal compared to the radial direction (Siau 1984). The vessels of hardwood possess a boundless extension due to the perforated cross-walls (Suchsland 1958). The standard deviations as well as Fig. $4 \mathrm{a}$ and $4 \mathrm{~b}$ indicate that the wax uptake in pine sapwood is more homogeneous in comparison with beech. The penetration depth increases with pressure and temperature. The longitudinal uptake of wax in pine ranges between 5 and $11 \%\left(24-57 \mathrm{~kg} \mathrm{~m}^{-3}\right)(4-12 \mathrm{bar})$ at $100^{\circ} \mathrm{C}$ and between 6 and $16 \%\left(30-78 \mathrm{~kg} \mathrm{~m}^{-3}\right)$ at $120^{\circ} \mathrm{C}$. Fig. 5 demonstrates that the penetration depth of wax in beech within 47 min exceeds the one in pine only marginally despite the presence of much longer vessel strands with a length between 800 and 2,000 mm

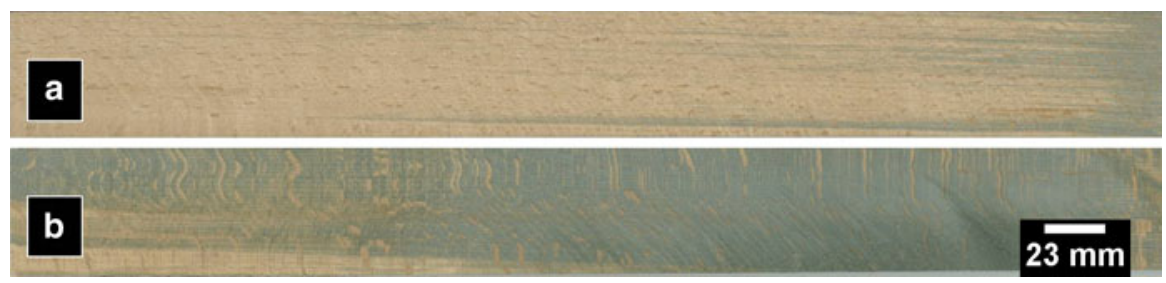

Fig. 3 Influence of time during the process treatment on beech $\left(12\right.$ bar at $\left.120^{\circ} \mathrm{C}\right)$ exemplified on longitudinal wax penetration. a Wax penetration for 47-min appearance like "zig-zag pattern", b wax penetration for $360 \mathrm{~min}$ 
Fig. 4 Lateral wax penetration within pine (a) and beech (b) (specimen size: $46 \times 46 \mathrm{~mm}$ )
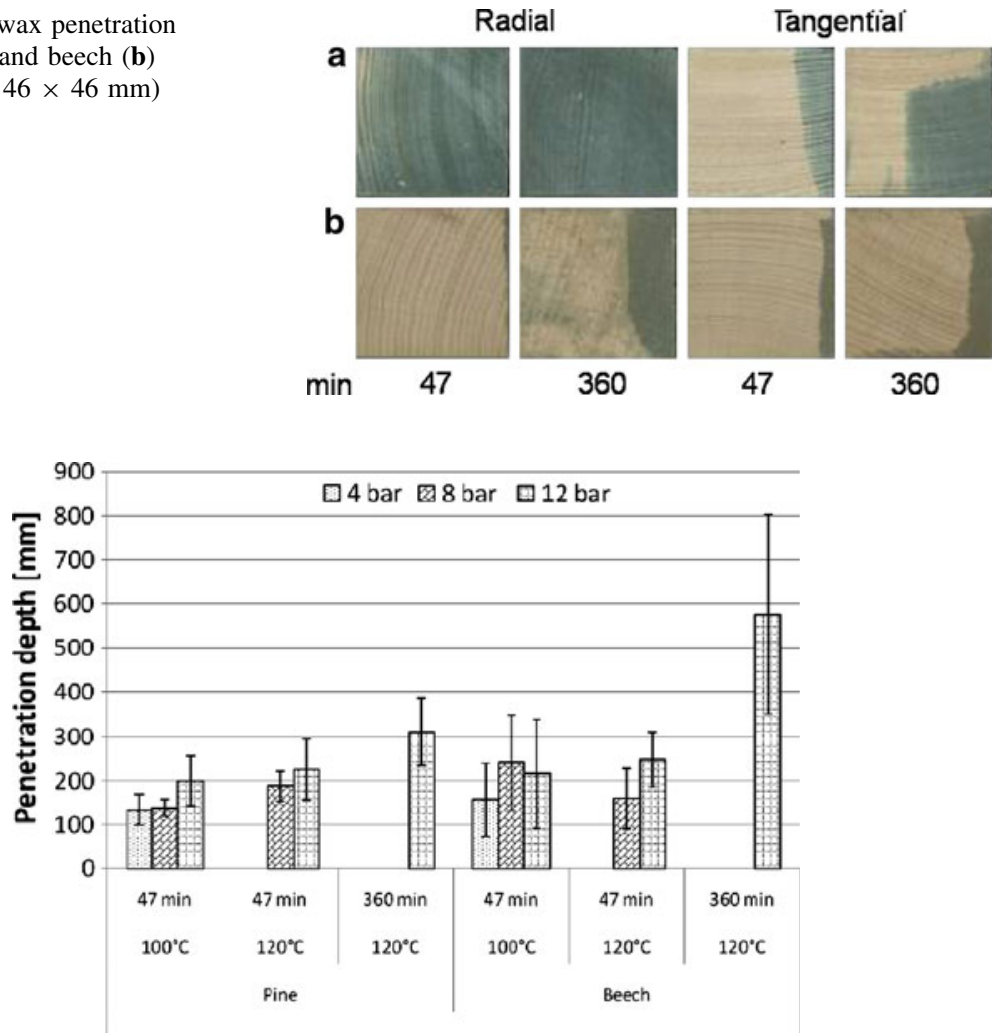

Fig. 5 Longitudinal wax penetration in pine and beech at varying pressure, temperature and process duration

(Braun 1970; Grosser 1977; Wagenführ 1984). Macroscopic observations showed that only a few vessels were completely filled with wax over the total specimen length of $1,000 \mathrm{~mm}$. That phenomenon could be explained by the low occurrence of long vessels in distinct diffuse-porous wood species (Skene and Balodis 1968; Middleton and Butterfield 1990). A pressure of 4 bar at $100^{\circ} \mathrm{C}$ causes an average penetration of $\sim 32 \mathrm{~mm}$ in the radial direction.

The kinetic effect is shown under consideration of the wax uptake for pine sapwood. The radial wax uptake at 12 bar increases from $59 \%\left(359 \mathrm{~kg} \mathrm{~m}^{-3}\right)$ at $100^{\circ} \mathrm{C}$ to $77 \%\left(435 \mathrm{~kg} \mathrm{~m}^{-3}\right)$ at $120^{\circ} \mathrm{C}$. The prolongation of the process duration from $47 \mathrm{~min}$ to $360 \mathrm{~min}$ causes an uptake of up to $91 \%$. According to Scholz et al. (2010b), this is in the range of fully impregnated Scots pine sapwood.

According to Fig. 5 and 6, increased temperature in the case of pine sapwood and especially prolonged process duration are more efficient for the tangential wax uptake (Fig. 4a). Furthermore, Fig. 4a demonstrates the blocking effect of heartwood tissue within pine, exemplified on the image with the tangential wax penetration. A prolongation of the process duration shows that the wax uptake is based on kinetic backgrounds especially for beech. An influence of effusing water 


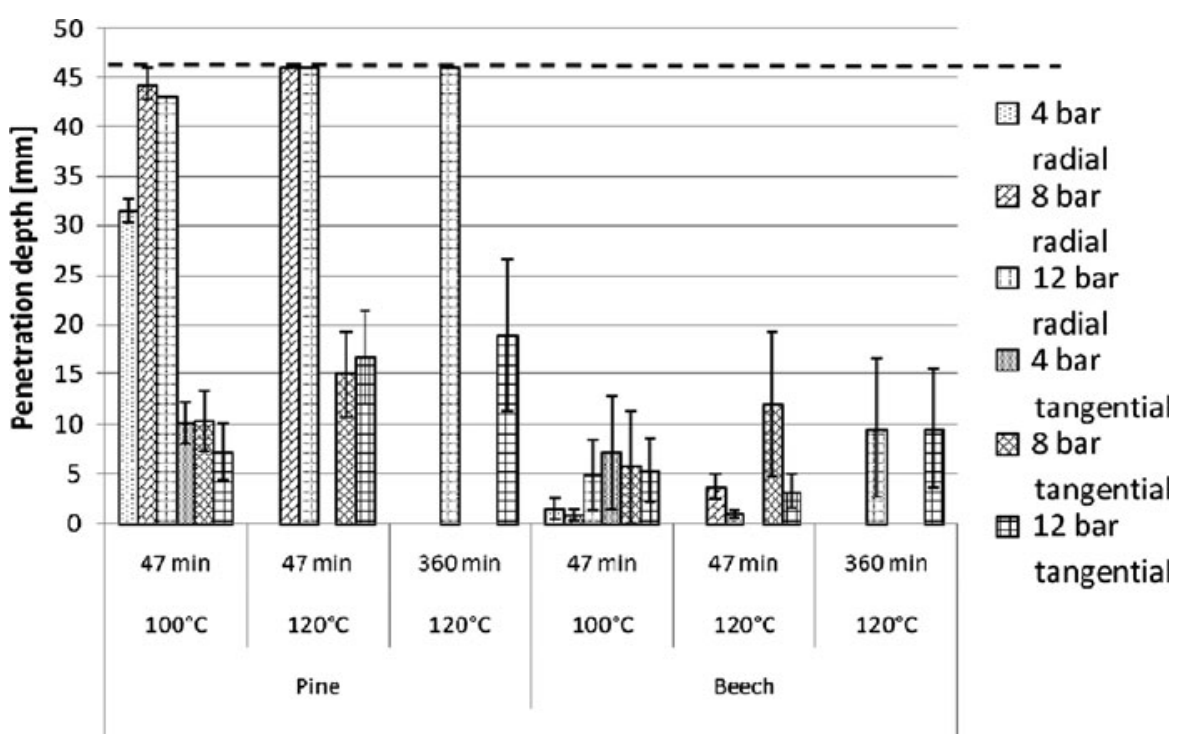

Fig. 6 Lateral wax penetration in pine and beech at varying pressure, temperature and process duration

steam on the wax uptake was excluded after 3 days of drying under 0.1 bar vacuum at $100^{\circ} \mathrm{C}$ and $120^{\circ} \mathrm{C}$, respectively. After a regular impregnation process of about $47 \mathrm{~min}$, beech shows an irregular wax penetration pattern (Fig. 3). This "zig-zagpattern" is possibly caused by the latewood vessels, which possess scalariform perforation plates according to Wagenführ (2007). During a process of $360 \mathrm{~min}$, the colored wax deposits indicate a more homogeneous pattern (Fig. 3). Furthermore, the penetration depth as well as the wax uptake increases from $4 \%$ (47 $\mathrm{min}$ ) to $30 \%$ (360 min), which complies to $28 \mathrm{~kg} \mathrm{~m}^{-3}$ and $373 \mathrm{~kg} \mathrm{~m}^{-3}$, respectively. These results are in accordance with Hackbarth (1978), who pointed out the importance of the process duration in combination with the pressure level.

In accordance with Bellmann (1987), liquid wax disperses like water-based solutions across the bordered pits of the ray tracheids into adjacent radial and longitudinal tracheids (Scholz et al. 2010a). For the lateral wax uptake and dispersion into adjacent longitudinal tracheids, the squarrose ray tracheids arranged in 1-3 rows (Wagenführ 2007) are important. The tangential wax dispersion is also possible locally across damaged window-like pits (Liese 1957; Scholz et al. 2010a). The tangential wax migration is more impeded.

Influence of viscosity and polarity of waxes during wood impregnation

The results of the determination of wax viscosity and surface tension are shown in Table 3 and Fig. 7. The influence of wax viscosity is already in Fig. 5 and 6. But at this point, the influence of viscosity and surface tension shall be discussed theoretically in detail.

The extension properties of water-based solutions within wood are basically different from those of liquid waxes. The internal friction of waxes is much higher 


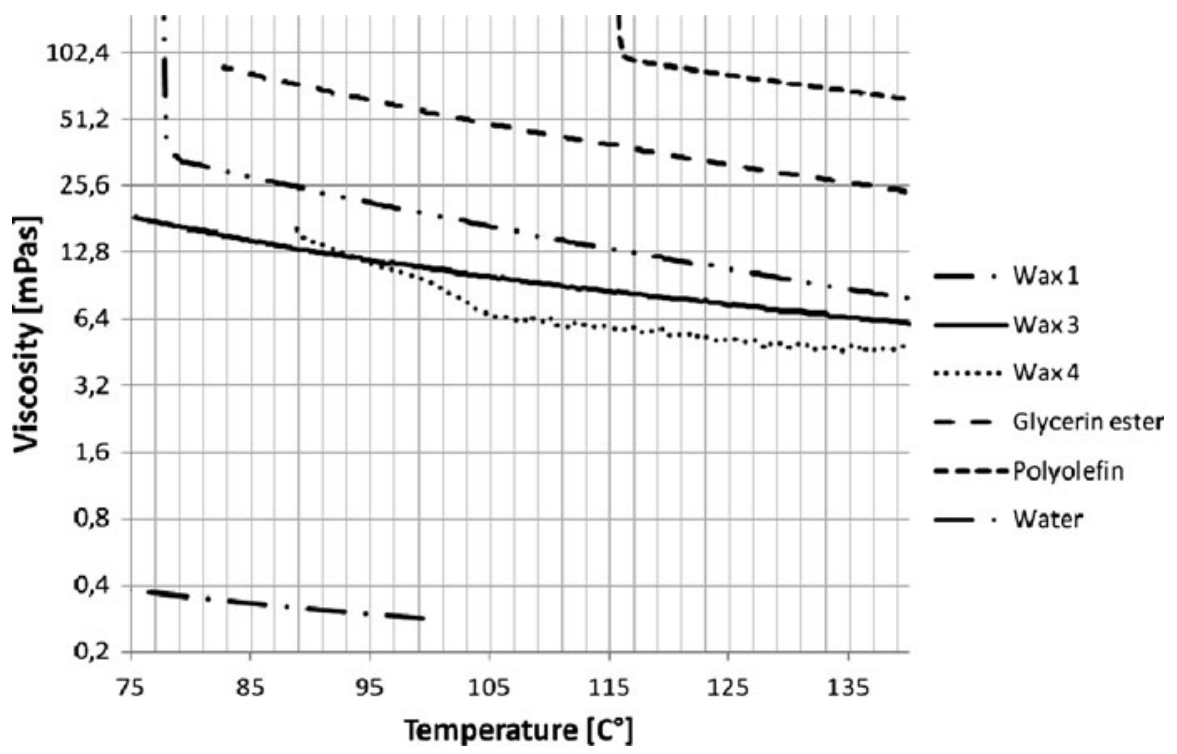

Fig. 7 Viscosity curves of different wax types ( $y$-axis with logarithmic scale on basis 2)

than between water molecules, interacting via hydrogen bonds, in consequence of the steric indenting of the aliphatic wax molecules. Atkins (1993) mentioned such indenting as a reason for the viscosity of heavy oil. In addition, dispersion forces of larger molecules also have an influence. Such dispersion forces are based on induced dipoles, which are caused by inner molecular electron motions. They were reduced disproportionately by an increasing molecule distance. As a matter of fact, unbranched wax molecules are closely packed according to Ivanovszky (1965). In accordance with Atkins (1993), dispersion forces probably influence the viscosity of waxes. The dynamic viscosity of wax 4 is $9.4 \mathrm{mPa} \mathrm{s}\left(100^{\circ} \mathrm{C}\right)$, which means more than nine times the viscosity of water $\left(20^{\circ} \mathrm{C}\right)$. The viscosity of wax 1 is more than 28 times of that of water (see Table 3 ). In practice, the melting points and temperaturedependent viscosities are important. Fig. 7 and Table 3 depict distinct viscous properties of waxes at a defined temperature. The viscous melts of the exemplified polyolefin can be attributed to the long molecule chains (3,000-20,000 $\left.\mathrm{g} \mathrm{mol}^{-1}\right)$ as well as (atactic, syndiotactic, isotactic) side chains. Scholz et al. (2010a) did not measure any swelling of the cell wall after wood impregnation with hot melting waxes.

The results indicate an increased indenting but also higher processing temperatures in the range of $150^{\circ} \mathrm{C}$ causing the beginning of wood decomposition (Militz and Mai 2008) and effusing gases. Due to that fact, wax penetration within the wood will be impeded. In contrast to the mentioned polyolefin, wax 4 has a low viscosity due to the lack of reactive groups and short molecule chains (Table 3, Fig. 6). The glycerin ester wax (Fig. 7) with a comparable molecule size to that of wax 4 is more viscous $\left(35 \mathrm{mPa} \mathrm{s}\right.$ at $\left.120^{\circ} \mathrm{C}\right)$. Because of an incomplete esterification of the polyvalent alcohol, free hydroxyl groups exist causing increased interaction with 
adjacent molecules and thus higher viscosity. Wax 3 is the heaviest of all waxes investigated but with a low melting point. According to Ivanovszky (1965), the low viscosity and the low melting point are caused by the low packing density of the branched wax molecule.

\section{Conclusion}

In accordance with Scholz et al. (2010a), the ray tracheids are important conductors within pine sapwood. For this reason, pine is easier to impregnate with liquid wax via the radial surface. Consequently, lower wax penetration in the tangential orientation can be explained. Scots pine sapwood can be fully impregnated via the radial surface. Even though beech is not easy to penetrate across the lateral surfaces, longer process duration causes high wax uptake across the longitudinal surfaces within long construction segments. Furthermore, the choice of higher temperature and other wax types influences the impregnation results. Waxes without or with low polarity penetrate the wood deeper than waxes with higher polarity, albeit similar molecule size and viscosity.

Acknowledgments The authors thank the Clariant Produkte Deutschland GmbH (Gersthofen) for providing the waxes and financial support of the project.

Open Access This article is distributed under the terms of the Creative Commons Attribution Noncommercial License which permits any noncommercial use, distribution, and reproduction in any medium, provided the original author(s) and source are credited.

\section{References}

Atkins PW (1993) Einführung in die Physikalische Chemie. VCH, Weinheim

Bellmann H (1987) Zur Bedeutung der Holzfeuchte bei der Kesseldrucktränkung von Nadelhölzern. Holz-Zbl. (126) 1857, 1858, 1862; (143) 2201-2203 (151) 2312, 2314, 2316

Borgin K, Corbett K (1970) The stability and weathering properties of wood treated with various waxes. Plast Paint Rubber 14:69-72

Braun HJ (1970) Funktionelle Histologie der sekundären Sproßachse. Das Holz. Handbuch der Pflanzenanatomie, vol. 9, part 1. Bornträger, Berlin Stuttgart

Bub-Bodmar F, Tilger B (1922) Die Konservierung des Holzes. Parey, Berlin

Buro A, Buro EA (1959) Beitrag zur Kenntnis der Eindringwege für Flüssigkeiten in Kiefernholz. Holzforschung 13:71-77

Feist WC, Mraz EA (1978) Protecting millwork with water repellents. Forest Prod J 28:31-35

Fengel D, Wegener G (2003) Wood-chemistry, Ultrastructure, reactions. Remagen, Kessel

Grosser D (1977) Die Hölzer Mitteleuropas. Springer, Berlin

Hackbarth W (1978) Untersuchungen über einige Grundlagen der Kesseldruck-Imprägnierung von Fichtenholz. Holz Roh- Werkst 33:97-99

Illmann G, Schmidt H, Brotz W, Michalczyk G, Payer W, Dietsche W, Hohner G, Wildgruber J (1983) Wachse. In: Bartholomé E, Ullmann F (eds) Ullmanns Enzyklopädie der technischen Chemie, Verlag Chemie, vol 24. Wachse bis Zündhölzer, Weinheim

Ivanovszky L (1965) Strukturmodelle der Wachse. Fette Seifen Anstrichm 67:762-769

Kollmann F (1951) Technologie des Holzes und der Holzwerkstoffe, vol 1. Springer, Berlin Göttingen München 
Liese W (1957) Der Feinbau der Hoftüpfel bei den Laubhölzern. Holz Roh Werkst 15:449-453

Middleton TM, Butterfield BG (1990) Vessel length distribution in the stems of three New Zealand species of Nothofagus. Wood Sci Technol 24:17-22

Militz H, Mai C (2008) Holzvergütung. In: Wagenführ A, Scholz F (eds) Taschenbuch der Holztechnik, Hanser, pp 485-500

Mundigler N, Rettenbacher M (2005) Natwood technology-A material thermal wood modification. In: Hill CAS, Militz H (eds) Proceedings of the second European conference on wood modification, Göttingen, pp 270-275

Murmanis L, Chudnoff M (1979) Lateral flow in beech and birch as revealed by the electron microscope. Wood Sci Technol 13:79-87

Scheiding W (2007) Weiterentwicklung eines Verfahrens zur Herstellung von wachsimprägniertem Thermoholz; Untersuchung der Holzeigenschaften und Ableitung von Einsatzmöglichkeiten, Final report, DBU-AZ 22257

Scholz G, Krause A, Militz H (2009) Capillary water uptake and mechanical properties of wax soaked Scots Pine. In: Englund F, Hill CAS, Militz H, Segerholm BK (eds) Proceedings of the fourth European conference on wood modification, Stockholm, pp 209-212

Scholz G, Van den Bulcke J, Boone M, Zauer M, Bäucker E, Militz H (2010a) Investigation on wax impregnated wood. Part 1: microscopic observations and 2D X-ray imaging of distinct wax types. Holzforschung, in press

Scholz G, Krause A, Militz H (2010b) Beeinflussung der Holzfestigkeit durch Wachstränkung. Holztechnologie 51:30-35

Sell J (1977) Hydrophobierende Holzimprägnierung-Wirkungsweise, Eigenschaften, Anwendungsmöglichkeiten. Holz Roh Werkst 35:75-78

Siau JF (1984) Transport processes in wood. Springer, Berlin

Skene DS, Balodis V (1968) A study of vessel length in Eucalyptus obliqua L'Herit. J Experimental Bot 19:825-830

Suchsland O (1958) Über das Eindringen des Leimes bei der Holzverleimung und die Bedeutung der Eindringtiefe für die Fugenfestigkeit. Holz Roh- Werkst 16:101-108

Unger A, Schniewind AP, Unger W (2001) Conservation of wood artifacts. Natural science and archeology. Springer, Berlin

Wagenführ R (1984) Anatomie des Holzes. VEB, Leipzig

Wagenführ R (2007) Holzatlas. Hanser, Leipzig

Wittmann J (2000) Physik in Wald und Flur. Deubner, Köln 